\title{
Rapid and Selective LC method for estimation of Duloxitine Hydrochloride
}

\section{Pushpa Kumari K*}

University College of Pharmaceutical Sciences, Andhra University, Visakhapatnam-530003, India

\begin{abstract}
The Duloxitine Hydrochloride was estimated by using a HPLC method. It was separated on a Waters symmetry $\mathrm{C}_{8}$ HPLC column $(250 \times 4.6 \mathrm{~mm}, 5 \mu)$ by passing mobile phase at a flow rate of $1.0 \mathrm{ml} / \mathrm{min}$ and the solution was monitored at a wavelength of $288 \mathrm{~nm}$. The retention time of the duloxitine was found to be $7.39 \mathrm{~min}$. The developed method was validated according to $\mathrm{ICH}$ guidelines. The developed method was accurate, precise and linear. This method can be successfully applied in quality control laboratories for routine analysis of duloxitine in pharmaceutical formulations.
\end{abstract}

Keywords: HPLC; Duloxitine hydrochloride; ICH; Validation

\section{Introduction}

Chemically duloxetine [1] is (+)-(S)-N-Methyl-3-(naphthalen1-yloxy)-3-(thiophen-2-yl) propan-1-amine. The empirical formula of duloxitine is $\mathrm{C}_{18} \mathrm{H}_{19} \mathrm{NOS}$. $\mathrm{HCl}$ and its molecular weight is 333.88 g. Chemical structure of duloxitine is given in Figure 1. It is available in 30 and $60 \mathrm{mg}$ capsules for oral administration. It is used as an antidepressant and also to treat major depressive disorder, general anxiety disorder, stress urinary incontinence, painful peripheral neuropathy and fibromyalgia. The antidepressant activity of duloxitine may be due to potentiation of serotonergic and noradrenaergic activity in the central nervous system.

Literature survey reveals that various UV [2-4] and HPTLC [5] methods have been reported for the estimation of duloxitine. The aim of the study is to develop and validate a sensitive, rapid, accurate and precise RP-HPLC method for quantification of duloxitine in bulk and its formulations.

\section{Materials and Method}

\section{Chemicals and reagents}

Duloxitine $\mathrm{HCl}$ working standard of $99.8 \%$ purity was obtained from Hetero Labs, Hyderabad. Duloxitine $\mathrm{HCl}$ capsules were procured from the local market. Acetonitrile \& Methanol of HPLC grade were obtained from Qualigens Fine Chemicals Ltd., Mumbai. All the other reagents such as disodium hydrogen phosphate, hydrochloric acid, tri fluoro acetic acid, sodium hydroxide potassium di hydrogen phosphate are of Analytical grade.

\section{Apparatus}

The separation of duloxitine was carried out on Waters alliance

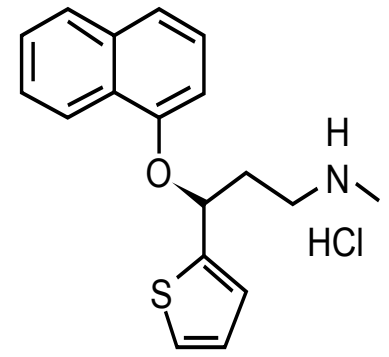

Figure 1: Chemical structure of duloxitine.
HPLC consisting of 2695 separation module, dual wavelength UV detector waters 2489 and output signal was monitored and integrated using Empower software.

\section{Assay method}

Preparation of mobile phase: Solution A: $2 \mathrm{ml}$ of Tri-fluoro acetic acid was transferred into a beaker containing $1000 \mathrm{ml}$ of Milli-Q water mixed and filtered through 0.45 membrane filter.

Solution B: $2 \mathrm{ml}$ of Tri-fluoro acetic acid was transferred into a beaker containing $1000 \mathrm{ml}$ of Acetonitrile, mixed and filtered through 0.45 membrane filter.

Mobile phase: It was prepared by mixing solution A and solution $B$ in the ratio of $55: 45 \% \mathrm{v} / \mathrm{v}$ and the solution were degassed prior to use.

Preparation of diluent

Diluent was composed of solution $\mathrm{C}$ and methanol in the ratio of $50: 50 \% \mathrm{v} / \mathrm{v}$.

Preparation of solution C:

1.41g Di-sodium hydrogen phosphate anhydrous was weighed and transferred into a beaker containing $1000 \mathrm{ml}$ of Milli-Q water and the solution was filtered through 0.45 membrane filter.

Standard preparation: Accurately about $68 \mathrm{mg}$ of Duloxitine $\mathrm{HCl}$ working standard was weighed and transferred into $100 \mathrm{ml}$ volumetric flask, $20 \mathrm{ml}$ of methanol was added, and sonicated to dissolve and make up to volume with diluent. From this $5 \mathrm{ml}$ of the solution was taken and diluted to $50 \mathrm{ml}$ with diluent.

Sample preparation: 10 capsules of Duloxitine $\mathrm{HCl}$ were weighed and contents of the capsules were emptied and mixed. Duloxitine $\mathrm{HCl}$ pellets equivalent to $60 \mathrm{mg}$ Duloxitine $\mathrm{HCl}$ was weighed and transferred

*Corresponding author: Pushpa Kumari K, Research Scholar, Pharmaceutica Analysis, University College of Pharmaceutical Sciences, Andhra University, Vishakapatnam-530003, India, Tel: 7702927897; E-mail: pushpa.pharma007@gmail.com

Received November 14, 2014; Accepted December 29, 2014; Published January 05, 2015

Citation: Pushpa Kumari K (2015) Rapid and Selective LC method for estimation of Duloxitine Hydrochloride. Pharm Anal Acta 6: 325. doi:10.4172/2153 2435.1000325

Copyright: (c) 2015 Pushpa Kumari K. This is an open-access article distributed under the terms of the Creative Commons Attribution License, which permits unrestricted use, distribution, and reproduction in any medium, provided the original author and source are credited. 


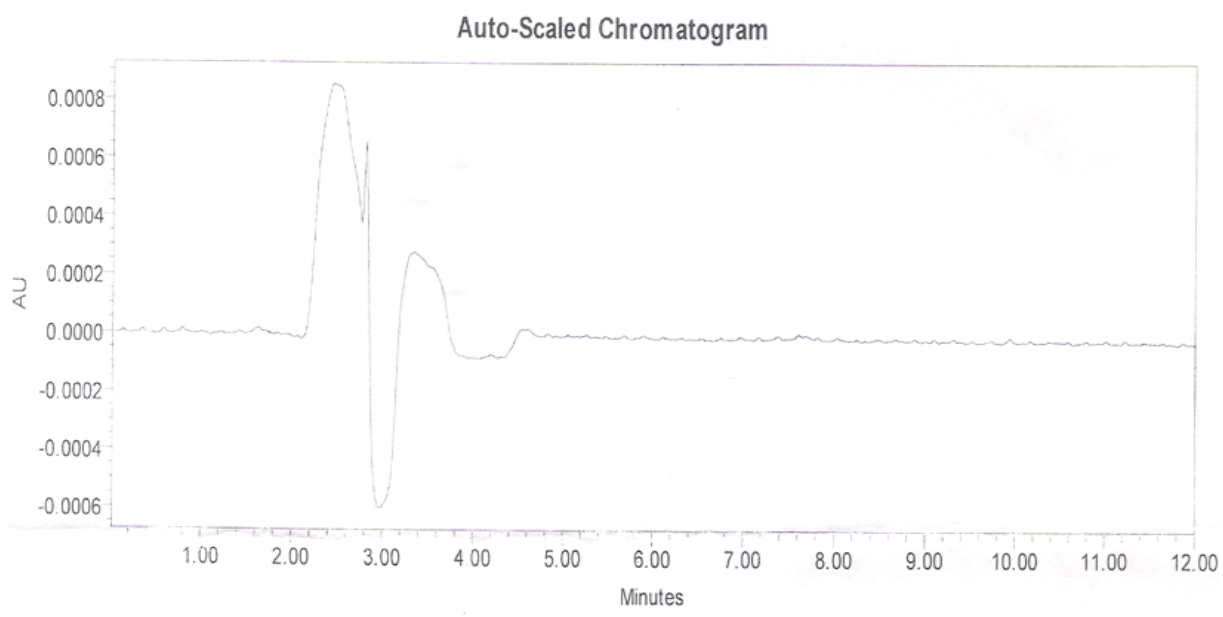

Figure 2: Chromatogram of placebo solution.

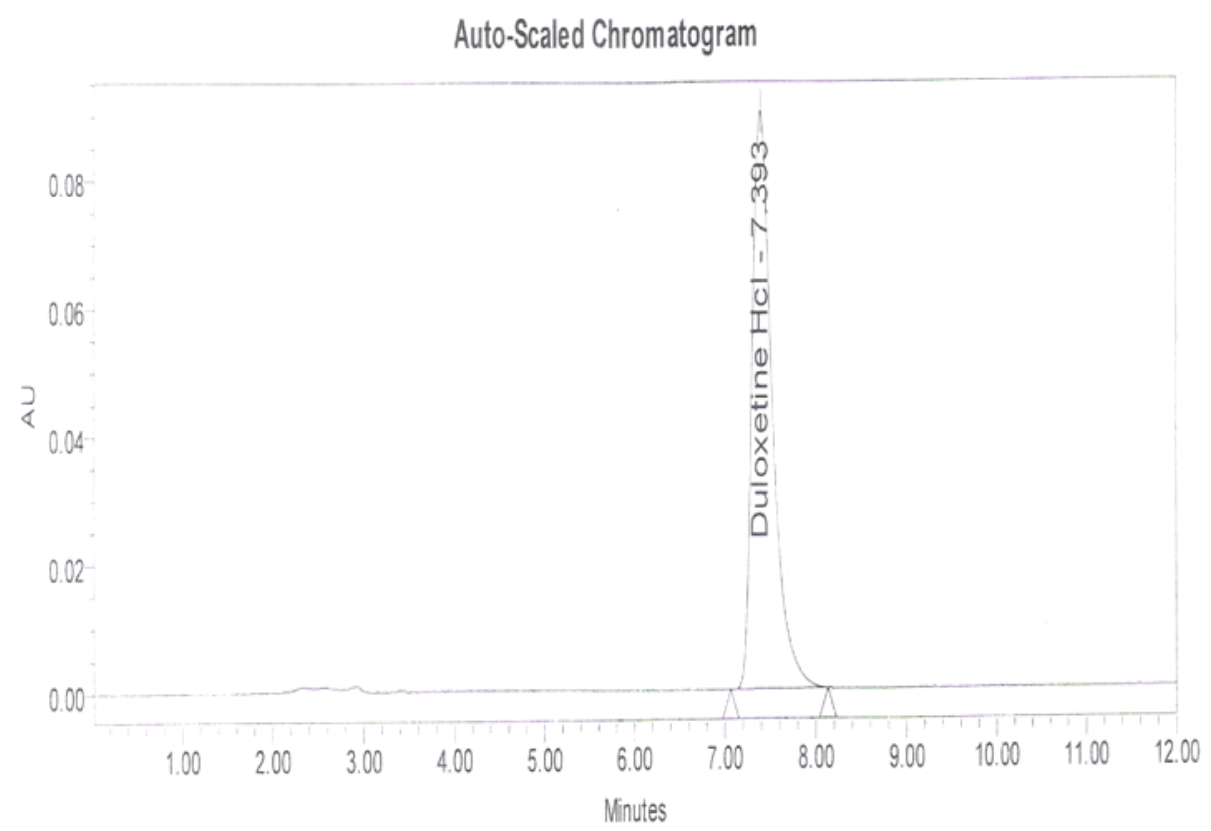

Figure 3: Chromatogram of Duloxetine Hydrochloride standard.

into a $100 \mathrm{ml}$ volumetric flask., $50 \mathrm{ml}$ of methanol was added and sonicated for $20 \mathrm{~min}$, with intermediate shaking until pellets completely dissolve (maintain the sonicate bath temp between 20-25) and about $20 \mathrm{ml}$ of buffer was added and again sonicated for $15 \mathrm{~min}$. and diluted to final volume with buffer. The resulting solution was mixed and centrifuged for $10 \mathrm{~min}$ at $5000 \mathrm{rpm} .5 .0 \mathrm{ml}$ of the clear supernatant solution was transferred into a $50 \mathrm{ml}$ volumetric flask and diluted to $50 \mathrm{ml}$ with diluent and mixed. The solution was filtered through 0.45 membrane filter.

Placebo preparation: Transfer placebo powder $(60 \mathrm{mg}$ equivalent weight of Duloxitine $\mathrm{HCl}$ ) into $100 \mathrm{ml}$ volumetric flask. Add $50 \mathrm{ml}$ of diluents dissolve and dilute to volume with mobile phase. Mix well. Centrifuge a portion of the sample at $3000 \mathrm{rpm}$ for 5 minutes. Transfer $5 \mathrm{ml}$ of this solution into $50 \mathrm{ml}$ volumetric flask and dilute to volume with diluent.
Procedure: The mobile phase was filtered through $0.45 \mu$ membrane filter before use, degassed and was pumped from the solvent reservoir into the Waters symmetry C 8 column at a flow rate of $1 \mathrm{ml} / \mathrm{min}$. The detection was monitored at $288 \mathrm{~nm}$ and the runtime was $10 \mathrm{~min}$. The placebo, standard and sample solutions were separately injected into the liquid chromatography and chromatograms were recorded (Figures 2-4). The amount of Duloxetine Hydrochloride present in pellets was calculated from the peak areas of recorded chromatograms.

\section{Method Validation}

The developed method [6,7] was validated as per ICH [8] guidelines.

\section{Specificity}

A study was conducted to demonstrate the effective separation of degradants from Duloxetine. Standard drug solution was exposed 


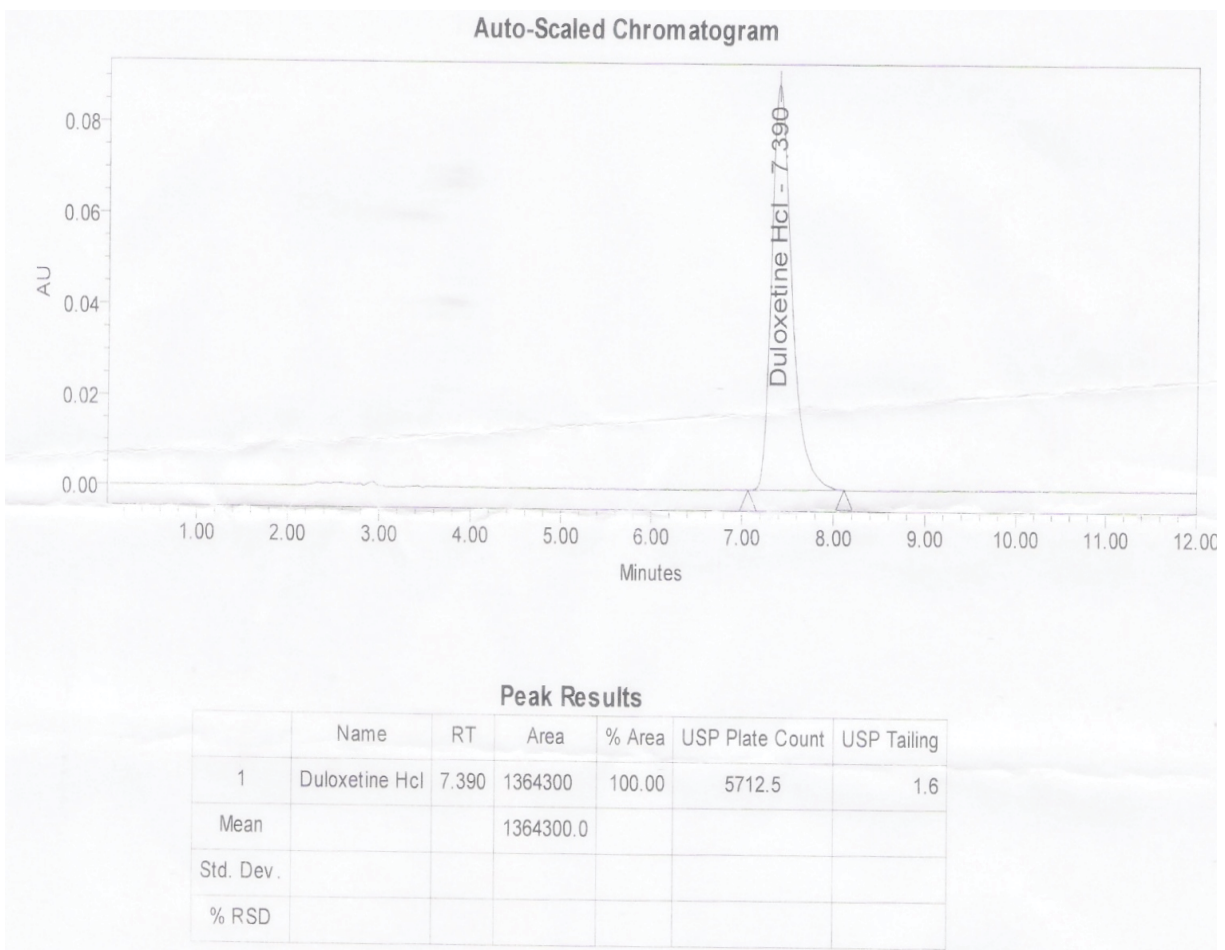

Figure 4: Chromatogram of Duloxetine Hydrochloride sample.

\begin{tabular}{|c|c|}
\hline S.No & Area of the peak \\
\hline 1 & 1394665 \\
\hline 2 & 1385176 \\
\hline 3 & 1394678 \\
\hline 4 & 1388509 \\
\hline 5 & 1400300 \\
\hline Average area & 1392666 \\
\hline standard Deviation & 5909.8 \\
\hline \%RSD & 0.4 \\
\hline
\end{tabular}

Table 1: Precision

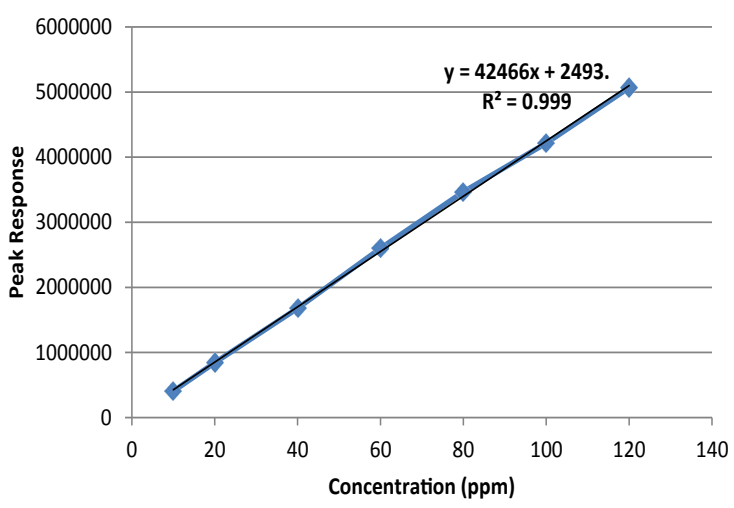

Graph 11: Linearity Curve of Duloxetine Hydrochloride.

to acid $(0.1 \mathrm{~N} \mathrm{HCl})$, base $(0.01 \mathrm{~N} \mathrm{NaOH})$, peroxide $\left(3.0 \% \mathrm{H}_{2} \mathrm{O}_{2}\right.$, and thermal $\left(105^{\circ} \mathrm{C}\right)$, UV light $(254 \mathrm{~nm})$ to induce the degradation. Stressed samples were injected into the HPLC system. All degradants peaks were resolved from Duloxetine peak in the chromatograms of all samples.

\section{Precision}

The precision of the method was tested by injecting six replicate injections of standard solutions into the chromatograpFhic system and the peak areas of the responses were recorded. The \%RSD (Relative Standard Deviation) for six injections should not be more than 2.0 (Table 1).

\section{Linearity}

Linearity of the analyte was performed by injecting $10 \%, 20 \%$, $40 \%, 60 \%, 80 \%, 100 \%$, and $120 \%$ of the standard concentration into the liquid chromatography and mean of the area were recorded. A graph of concentration against peak area was plotted and correlation coefficient was calculated from the graph (Graph 1). the correlation coefficient should be not less than 0.99 (Table 2).

\section{Accuracy}

The percentage recovery of the standard was determined by spiking known concentration of standard to the placebo matrix at three different concentrations (50\%, $100 \%$ and $150 \%$ of Duloxetine Hydrochloride) in triplicate. The percentage recovery should be between 95 to105percent (Table 3).

\section{Robustness}

The robustness of the analytical method was estimated by checking the system suitability under deliberately modified chromatographic conditions (flow rate, mobile phase ratio) and \% RSD values were calculated (Table 4)

\section{Ruggedness}

The Ruggedness of the analytical method was estimated by testing 


\begin{tabular}{|c|c|c|}
\hline Linearity & Concentration $\mathbf{( p p m )}$ & Response \\
\hline 1 & 10 & 406198 \\
\hline 2 & 20 & 844162 \\
\hline 3 & 40 & 1677435 \\
\hline 4 & 60 & 2598515 \\
\hline 5 & 800 & 3468416 \\
\hline 6 & 100 & 4215690 \\
\hline 7 & 120 & 5067282 \\
\hline \multicolumn{2}{|c|}{ Correlation Coefficient } \\
\hline \multicolumn{2}{r}{} \\
\hline
\end{tabular}

Table 2: Linearity Data.

\begin{tabular}{|c|c|c|c|c|}
\hline Concentration & $\begin{array}{c}\text { Amount } \\
\text { added (ppm) }\end{array}$ & $\begin{array}{c}\text { Amount } \\
\text { found(ppm) }\end{array}$ & \%Recovery & $\begin{array}{l}\text { Statistical } \\
\text { Analysis }\end{array}$ \\
\hline $50 \%$ spl-1 & 40.32 & 39.80 & 98.7 & \multirow{3}{*}{$\begin{array}{c}\text { Mean }=99.5 \% \\
S D=0.71 \\
\% R S D=0.71\end{array}$} \\
\hline $50 \%$ spl-2 & 40.51 & 40.55 & 100.1 & \\
\hline $50 \%$ spl-3 & 39.96 & 39.80 & 99.6 & \\
\hline $100 \%$ spl-1 & 80.11 & 80.35 & 100.3 & \multirow{3}{*}{$\begin{array}{c}\text { Mean }=99.7 \% \\
\text { SD }=0.60 \\
\% \text { RSD }=0.60\end{array}$} \\
\hline $100 \%$ spl-2 & 79.98 & 79.26 & 99.1 & \\
\hline $100 \%$ spl-3 & 80.26 & 80.10 & 99.8 & \\
\hline $150 \% \mathrm{spl}-1$ & 118.95 & 117.64 & 98.9 & \multirow{2}{*}{$\begin{array}{c}\text { Mean }=99.4 \% \\
\text { SD }=0.55 \\
\% \text { RSD }=0.55\end{array}$} \\
\hline $\begin{array}{l}150 \% \text { spl-2 } \\
150 \% \text { spl-3 }\end{array}$ & $\begin{array}{l}120.05 \\
120.47\end{array}$ & $\begin{array}{l}119.33 \\
120.47\end{array}$ & $\begin{array}{c}99.4 \\
100\end{array}$ & \\
\hline
\end{tabular}

Table 3: Accuracy data.

\begin{tabular}{|c|c|c|}
\hline Chromatographic parameter & Conditions & \% RSD \\
\hline & $0.8 \mathrm{ml}$ & 1.44 \\
& $1 \mathrm{ml}$ & 0.93 \\
Flow Rate & $1.2 \mathrm{ml}$ & 1.50 \\
& & \\
Mobile Phase & $50 / 45$ & 0.44 \\
(Organic/aqueous) & $55 / 45$ & 0.93 \\
& $60 / 45$ & 0.90 \\
\hline
\end{tabular}

Table 4: Robustness.

\begin{tabular}{|c|c|c|c|}
\hline \multirow{2}{*}{ S.NO } & \multirow{2}{*}{ Data File } & \multicolumn{2}{|c|}{ \% Assay } \\
\cline { 3 - 4 } & & Analyst-1 & Analyst-2 \\
\hline 1 & Sample--001 & 99.6 & 98.8 \\
\hline 2 & Sample--002 & 101.2 & 100.1 \\
\hline 3 & Sample--003 & 98.5 & 99.6 \\
\hline 4 & Sample--004 & 100.2 & 98.8 \\
\hline 5 & Sample--005 & 99.1 & 98.5 \\
\hline 6 & Sample--006 & 99.8 & 100.6 \\
\hline & Average & 99.7 & 99.4 \\
\hline & SD & 0.93 & 0.84 \\
\hline & $\%$ RSD & 0.93 & 0.84 \\
\hline
\end{tabular}

Table 5: Ruggedness. assay of six different test solutions for the same batch under different Analyst on different days and \%RSD was calculated (Table 5).

\section{Results and Discussion}

Under Optimised chromatographic conditions, the retention time of duloxitine was found to be 7.39. The system suitability factors were within the limits. Tailing factor and theoretical plates were 1.6 and 5712 respectively. The \%of the drug in the marketed formulation was in between 98.5-101.2. The \% RSD values for precision and ruggedness were $0.93 \%$ and $0.84 \%$ respectively. The method was linear over the concentration range 10-120 ppm with correlation coefficient of 0.999 . The mean \%recoveries lie between $99.4-99.7 \%$.

\section{Conclusion}

The proposed HPLC method is rapid, sensitive, precise and accurate for the determination of duloxitine $\mathrm{HCl}$ and can be reliably adopted for routine quality control analysis of duloxitine $\mathrm{HCl}$ in bulk and its pharmaceutical formulations.

\section{Acknowledgement}

Special thanks to Hetero Laboratories, Hyderabad for providing the samples of duloxitine.

\section{References}

1. www.rxlist.com

2. Vijay R, Amirtha Raj, Ramesh T, Phani Kumar A (2011) A Validated UV spectrophotometric determination of an antidepressant drug- duloxitine $\mathrm{HCl}$ from capsule formulations. International Journal of Pharma and Biosciences 2: 716 .

3. Kamila MM, Mondal N, Ghosh LK (2007) A Validated UV spectrophotometric determination of duloxitine $\mathrm{HCl}$. Pharmazie 62: 414-415.

4. Kishore Methuku, Kiran Aarelly, N.Raghunandan, Manish Kumar Thimmaraju (2012) Journal of pharmaceutical and scientific innovation 3.

5. Suneela S Dhaneshwar, P Deshpande, A Patil, G Vadnerkar, SR Dhaneshwar (2008) Development and validation of a HPTLC method for estimation of duloxitine $\mathrm{HCl}$ in bulk drug \& in tablet dosage form. Indian J Pharm Sci: 70.

6. Braun RD (1982) Introduction to Chemical Analysis, Mc Graw-Hill Book Co.Singapore pp: $342-345$.

7. Lloyd R Snyder; Joseph J Kirkland, Joseph L Glajch (1997) Practical HPLC Method Development ( $2^{\text {nd }}$ Edn) A wiley Interscience Publication, John willey \& sons, INC., United States of America, Pp: 208-210.

8. $\mathrm{ICH}$ guidelines on validation of Analytical Procedure: Text \& Methodology: Q2(R1). 